ent routes equally well, suggesting that the two paths were integrated into a single cognitive map (i.e., that the relationships between paths and within paths were equally available). These learning conditions were similar to those in the Levine et al. experiments, in which subjects could integrate all the path segments during acquisition because they were presented with the layout in a continuous sequence. Moar and Carleton also found that the repeated presentation of the routes improved the accuracy of the subjects' spatial judgments.

This finding is quite different from the present results for the effects of training. An account of this difference might be that subjects in the Moar and Carleton studies had many opportunities to integrate the paths more accurately and completely with the repeated presentation of the routes. In the present experiments, the repeated tracing of the individual paths only gave the subjects the opportunity to learn the separate paths, because the subjects could only integrate the layouts after the acquisition of the spatial information. In conclusion, the time at which integration occurs during the learning of a spatial layout appears to be influential in the acquisition and accuracy of survey knowledge.

\section{REFERENCE NOTE}

1. Shemyakin, F. N. Orientation in space. In B. G. Ananyev, G. S. Kostyuk, A. N. Leontyev, A. R. Luria, M. A. Menchinskaya, S. L. Rubinshteyn, A. A. Smirnov, B. M. Teplov, \& F. N. Shemyakin (Eds.), Psychological science in the USSR (Vol. 1) (Tech. Rep. 11466, Pt. 1). Washington, D.C: U.S. Office of Technical Reports, 1962.

\section{REFERENCES}

APPLEYARD, D. Styles and methods of structuring a city. Environment and Behavior, 1970, 2, 100-118.

Chase, W. G., \& Chi, M. T. H. Cognitive skill: Implications for spatial skill in large-scale environments. In J. Harvey (Ed.), Cognition, social behavior and the environment. Potomac, MD: Erlbaum, 1980.
Downs, R. M. Maps and mapping as metaphors for spatial representation. In L. S. Liben, A. H. Patterson, \& N. Newcombe (Eds.), Spatial representation and behavior across the life span: Theory and application. New York: Academic Press, 1981.

Downs, R. N., \& SteA, D. Image and environment: Cognitive mapping and spatial behavior. Chicago: Aldine, 1973.

Levine, M., Jankovic, I. N., \& Palis, M. Principles of spatial problem solving. Journal of Experimental Psychology: General, $1982,111,157-175$.

LYNCH, K. The image of the city. Cambridge, Mass: M.I.T. Press, 1960.

Moar, I., \& Carleton, L. R. Memory for routes. Quarterly Journal of Experimental Psychology, 1982, 34A, 381-394.

MYERS, J. L. Fundamentals of experimental design (3rd edition). Boston: Allyn \& Bacon, 1979.

Siegel, A. W. The externalization of cognitive maps by children and adults: In search of ways to ask better questions. In L. S. Liben, A. H. Patterson, \& N. Newcombe (Eds.), Spatial representation and behavior across the life span: Theory and applica. tion. New York: Academic Press, 1981.

Sieget, A. W., Kirasic, K. C., \& KaIl, R. V. Stalking the elusive cognitive map: The development of children's representations of geographic space. In J. F. Wohlwill \& I. Altman (Eds.), Human behavior and environment (Vol. 3). New York: Plenum, 1978.

Siegel, A. W., \& White, W. H. The development of spatial representations of large-scale environments. In $\mathbf{H}$. W. Reese (Ed.), Advances in child development and behavior (Vol. 10). New York: Academic Press, 1975.

Tolman, E. C. Cognitive maps in rats and men. Psychological Review, 1948, 55, 189-208.

\section{NOTES}

1. The decrease in mean absolute angle errors was not due to systematic biases in movements, because the variability in angle error also decreased as the memory ratings increased. If systematic movement biases were responsible for the progression of angle errors, the variability in angle error would not have continually decreased from an almost random level of performance to a very accurate level. The standard deviations of angle error were $49.53,45.24,40.39,32.30$, and $12.89 \mathrm{deg}$ for the $1-2$ to 9-10 memory-rating categories, respectively.

2. The Bonferroni $t$ is a test statistic for nonorthogonal contrasts (Myers, 1979) and is appropriate for these comparisons.

(Manuscript received October 12, 1982; revision accepted for publication April 8, 1983.)

\title{
24th ANNUAL MEETING OF THE PSYCHONOMIC SOCIETY, INC.- CORRECTED DATES
}

\begin{abstract}
Announcement-24th Annual Meeting of The Psychonomic Society, Inc. (Bulletin of the Psychonomic Society, 1983, 21, 324; Perception \& Psychophysics, 1983, 34, 193)-Please note that the wrong dates for the 1983 meeting were provided. The correct dates for this year's meeting are those on the Program, November 17-19, 1983.
\end{abstract}

